\title{
METAFÍSICA, VIOLÊNCIA E CONTEMPORANEIDADE: INTERPELAÇÕES ÉTICAS A PARTIR DA FILOSOFIA DE LÉVINAS
}

\author{
METAPHYSICS, VIOLENCE AND CONTEMPORARYITY: \\ ETHICAL INTERSPELATIONS FROM THE PHILOSOPHY OF LÉVINAS
}

Nilo Ribeiro Junior ${ }^{*}$

\begin{abstract}
RESUMO:
$\mathrm{O}$ artigo visa refletir sobre a tensão que perpassa a tradição metafísica da filosofia ocidental e as questões que se lhe apresentam na contemporaneidade. Em função disso, trata-se de ir ao âmago do problema filosófico que escolhemos como objeto desta investigação, a saber, a iteração entre violência e metafísica, seja em vista de desvendar os motivos da face belicosa da filosofia greco-romana e suas antinomias diante da cultura e o pensamento atual, seja com a intenção de anunciar uma "outra maneira de uma filosofia da paz" avessa à totalidade da razão e do Ser. Uma filosofia que, sem cair na ingenuidade de imiscuir-se da negatividade do real, permita aproximar-nos de um saber paradoxal contrário à tese dóxica da razão e do ser, e que seja capaz de abrir o pensamento para uma metafísica pós-metafísica da alteridade, concebida segundo a intriga do amor e da justiça e presidida pela interpelação do Rosto do outro e do terceiro da relação.
\end{abstract}

PALAVRAS CHAVE: Metafísica. Violência. Ética. Paradoxo. Rosto.

\section{ABSTRACT:}

The paper aims to ponder on the tension that permeates the metaphysical tradition of Western philosophy and the contemporary issues related to it. It is important to go in depth about the philosophical problem that we have chosen as the object of this investigation, namely, the iteration of violence and metaphysics, either in order to uncover the reasons of the warlike face of Greco-Roman philosophy and its antinomies when facing culture and current thought, or with the intention of announcing another way for a "philosophy of peace", contrary to the totality of Reason and Being. A philosophy that, without falling into the naiveté of interfering with the negativity of the real, allows us to approach a paradoxical knowledge contrary to the doxic thesis of reason and being, and to be able to open the thinking process to a postmetaphysics of otherness, conceived according to the quarrel of love and justice and presided over by the interpellation of the Face of the other and the Third of the relationship.

KEY WORDS: Metaphysics. Violence. Ethics. Paradox. Face.

\footnotetext{
* Professor do PPG de Mestrado em Filosofia e Teologia da FAJE. Coordenador do CEBEL: Centro Brasileiro de Estudos Levinasianos. Coordenador do GT-Lévinas ANPOF. E-mail: prof.ribeironilo@gmail.com.
} 


\section{INTRODUÇÃO}

Diante da indubitável iteração entre o binômio violência e metafísica que, portanto, põe à prova a pretensão da segunda, somos interpelados a debruçar sobre as indagações e desafios que a visível exacerbação da primeira no contexto da contemporaneidade apresenta para a filosofia ocidental. Desde seus primórdios, a face metafísica da filosofia greco-romana reivindicara para si a tarefa de pensar os fundamentos do real para além da incerteza, do provisório, do equívoco, da finitude, enfim, do caos que, em certo sentido, atravessa o real. Aprouve-lhe fixar como meta a articulação das questões do homem, do mundo e de Deus em bases sólidas que assegurasse uma sintaxe dessa tríade em torno da razão, embora a filosofia tenha consciência das tensões que a movem e da necessidade de seu pensamento levar em consideração “o concreto mais 'antigo' que a pura forma do tempo" a fim de evitar entregarse a um esforço meramente especulativo (LÉVINAS, 1997a, p. 227).

Em contrapartida, nota-se em nossas culturas uma galopante aversão aos metarrelatos e aos ethoi vinculados às diversas tradições, religiões e morais, etc., e, por antonomásia, uma forte desconfiança em relação à afirmação do Sentido embasada numa visão unívoca e totalizante da verdade, no Logos, e em sua respectiva lógica, sinônimo de clareza, de evidência, sempre referida ao ser. Esse impasse, que afeta diretamente a metafísica, se deve à percepção daquilo que alguns filósofos, parafraseando Kant, identificam como antinomias contemporâneas da razão. Essas ocorrem pelo fato de a metafísica se contrapor à irracionalidade, em nome da razão quando a própria razão, e a linguagem com que essa se dá prenunciam o fracasso da filosofia diante da impossível tarefa de dirimir as questões do mal ético e da injustiça, que assolam todas as formas de vida na contemporaneidade.

Eis que, do ponto de vista epistemológico, teremos de nos ocupar da contradição interna da metafísica, uma vez que toda tentativa de delimitar o discurso e propugnar uma posição no Logos, pressupõe uma deliberada exclusão de outra perspectiva ou de outro enquadramento da verdade. Nessa ótica, a filosofia não pode desvencilhar-se das questões da violência pelo fato de enaltecer a argumentação por meio do exercício sensato da linguagem e da retórica em nome da coerência da razão que subjaz ao seu discurso (LÉVINAS, 1987, p. 206). Além disso, como desde seus primórdios a arte de filosofar se caracteriza pelo "amor à Sabedoria", resta saber se esse amor, ao qual ela se refere e enfatiza sobremaneira ao longo de sua tradição, não seria uma outra forma de colonização do saber e, consequentemente, se a tendência à hegemonia do poder pelo pensar não põe em xeque tal sabedoria a qual a filosofia 
se propõe como forma autêntica de assegurar o acesso pleno à verdade.

Diante desses desafios, trata-se de insistir que ao longo do percurso desta investigação nos deteremos nos problemas que a violência coloca para a metafísica. Isso porque, se por um lado a última se revela coetânea da primeira, resta saber se há alguma chance de a metafísica poder se liberar do ônus da violência que a torna refém da aporia de uma desrazão no Logos. Após estabelecer o estado da questão, daremos outros passos no sentido de apresentar traços históricos do problema filosófico da metafísica a fim de circunscrever e localizar melhor o nível em que se põe o debate. Em seguida, a reflexão visa apresentar uma maneira de pensar a metafísica segundo "o outro modo de ser" propugnado pela ontologia contemporânea e, por último, de avançar em direção a uma metafísica pós-metafísica e, portanto, que permita concebê-la como "outra maneira que Ser" não para rechaçá-la, mas para submetê-la aos critérios da alteridade do outro e com ela à alteridade do real. Pensamos que essa "outra maneira que o Ser" da metafísica permite situá-la no bojo da contemporaneidade em função de seu estatuto paradoxal para além da ontologia. Isso talvez lhe permita uma via de saída dos dilemas que, em princípio, se mostram insolúveis se mantém a metafísica cativa da racionalidade que a faz totalizante. Ora, quando interpelada pela alteridade de outrem que vem de alhures, a metafísica pareceria fissurada a ponto de mudar de estatuto e de poder oscilar entre o Dizer originário do amor (ética) e o Dito ou discurso da justiça.

\section{ESTADO DA QUESTÃO: AS ANTINOMIAS DA RAZÃO NA CONTEMPORANEIDADE}

Ao lado dos inúmeros problemas evocados há pouco, soma-se a crescente fratura do simbólico e da fragmentação do real que incide diretamente na percepção da violência que o atravessa (o real) e que o expõe à situação extrema de perplexidade a ponto de colocar em questão as certezas que outrora permitiam um discurso filosófico linear do sentido. Assiste-se, pois, em nossa época, à disseminação dos mais variados e acirrados embates culturais entre indivíduos, grupos e sociedades, etnias, raças, gêneros etc., muito embora se observe também um crescente anseio, em meio a esses impasses, de se assegurar e promover o reconhecimento do diferente e das diversidades como maneira de refazer o tecido social local e mundial, esgarçado pelas guerras, pelo empobrecimento e por toda sorte de exclusão que atinge a humanidade se pensada não tanto em função do antropocentrismo eurocêntrico, mas de um cosmopolitismo, levando-se em conta que os problemas humanos aparecem cada vez mais intimamente ligados à natureza, à ecologia, ao biopoder e às biopolíticas. E, apesar dos 
entraves que dificultam compaginar a força destruidora da violência e a fragilidade do desejo, subjaz a essa intenção o surpreendente e inesperado propósito de grupos e sociedades em dirimir os conflitos em nome da bondade, do amor, da convivência, da concórdia, da justiça e da paz entre povos e nações, sexos e etnias. Talvez, por essa razão, muitos advoguem a impossibilidade de escapar dos dilemas que se põem à Metafísica. Jacques Derrida pode ser evocado nesse contexto por sua crítica ao que ele denomina fechamento da história pela metafisica, que aborda a diferença por meio do saber e do pensar globalizado em torno da univocidade de sentido.

\begin{abstract}
A história do ser como presença, como presença a si no saber absoluto, como consciência de si na infinidade da parusia, esta história está encerrada. A história da presença está encerrada porque história nunca quis dizer mais do que isso: presentação do ser, produção e recolhimento do ente na presença, como saber e domínio. Dado que a presença plena tem vocação de infinidade como presença absoluta a si mesmo na cons-ciência, a realização do saber absoluto é a finalidade do infinito que só pode ser a unidade do conceito, do logos e da consciência numa voz sem diferência. A história da metafísica é o querer-ouvir-se-falar absoluto. (DERRIDA, 1996, p. 121).
\end{abstract}

Dentre outros motivos da apelação epistemológica, sobressai aquele que, frente às críticas, a pretensão de universalismo em detrimento das diferenças, faz com que a metafísica se arme não poucas vezes de uma atitude defensiva e apologética, alegando a especificidade de seu objeto em torno de uma Filosofia Primeira. Nesse ínterim, ela acaba por remeter a questão da transformação do mundo e da história tanto à ética e à moral como à política e à religião (NANCY, 2002, p. 87); também lhes atribui o caráter prático em função da contiguidade dessas áreas do saber com o mundo da ação, enquanto o ideal da metafísica orienta-se para a contemplação, como forma mais pura e acabada de filosofar, baseada, pois, num saber totalizante marcado pela indiferença ao diferente, de modo a contrapor-se a qualquer saber de caráter singular.

\title{
2 A SUSPEITA E O FIM DA METAFÍSICA
}

Há de se recordar que mesmo alguns de seus atuais defensores recordam que a Metafísica não pode se esquivar das aporias do pensamento e, porque não dizer, de certas antinomias, pelo próprio fato de se apoiar na ideia da universalidade da Razão e de sua Lógica (dogmática), mesmo considerando que os paradigmas filosóficos tenham variado ao longo da história da filosofia (NANCY, 2002, p. 92). Ora, sabe-se por experiência que mesmo sendo 
fidedigna ao caráter predominantemente intelectual e racionalista, a metafísica não pode ignorar nem deixar de aproximar seu projeto da busca pela sabedoria paradoxal em "função do logos de um pro-logos" (LÉVINAS 2011, p. 27). Isso se deve ao fato de que ela brota das questões que advêm da concretude da vida fora da essência (LÉVINAS, 2011, p. 26) da qual ninguém poder se retirar para pensá-las numa espécie de pensamento desencarnado. Por sua vez, a ênfase na facticidade da vida nos recorda que essa se retira da evidência porque está entranhada visceralmente na existência. Portanto, se a metafísica pretende evitar cair em contradição e ser classificada segundo a clássica evocação aristotélica da "petição de princípio", ela terá que abrir-se para aquilo de onde tira suas falsas seguranças calcadas no argumento da autoridade ou da razão, quando a própria razão emerge do fundo do real do qual ninguém tem acesso a priori ou a partir de um exercício dedutivo em detrimento do sentido e do vivido fora da essência (LÉVINAS, 2011, p. 26). Nessa esteira, pontua o filósofo francolituano Emmanuel Lévinas:

\begin{abstract}
A filosofia chocou-se com o seu não-sentido nas suas ambições e seus caminhos próprios. Ora, acontece que, para além de sua presença imediata, os seres podem aparecer de alguma forma sem permanecer no seu ser [...] A razão do saber deveria desconfiar de certos jogos que enfeitiçam o exercício espontâneo do conhecimento que o enfeitiçam sem se dar conta disso - sem deter e nem sequer estorvar seu processo racional. Insegurança do racional que, consequentemente, frustra uma inteligibilidade em que a segurança, a seguridade do fundamento é a razão mesma. (LÉVINAS, 2002, p. 158).
\end{abstract}

Do mesmo modo, a tentativa de superar as contradições e as aporias não deixa de levantar suspeitas à metafísica por parte de seus opositores. Estes alegam que, em certos momentos fundamentais de sua história, a filosofia parece ter-se chafurdado em certo tipo de violência exatamente em função de seu ideário epistemológico que se impôs na modernidade por meio do advento da autonomia, como no caso do kantismo, a ponto de contrapô-lo ao caráter ontológico do saber. Em função disso, a metafísica se tornou mais preocupada em referendar a coerência e a clareza de seus respectivos axiomas e sistemas filosóficos fundados no paradigma das ciências empírico-formais importado para as ciências humanas, do que em ocupar-se da tarefa primordial de promover e proteger as Humanidades em suas ambivalências das quais reivindicara inicialmente ser porta-voz. E quando o fizera, muitas vezes abstraíra o paradoxo e as contradições que habitam a Existência humana e o mundo no interior do qual essa tensão se instaura. Afinal, não se pode ignorá-las nem se desfazer delas como se não se bastassem em sua própria densidade ontológica como condição possível para 
toda e qualquer metafísica fundada na razão moderna. Daí o fato de as perguntas decorrentes da constatação sobre a metafísica não deixarem de ser provocantes para a contemporaneidade. Isso nos induz a formulá-las como itinerário de nossa investigação, no sentido de perguntar se não seria a própria "invenção da metafísica" uma maneira velada de referendar a tese dóxica ou a lógica da representação (LÉVINAS, 1997a, p. 101) como forma de violência do pensamento marcado pela busca da totalidade (p. 32), isto é, do discurso coerente em torno do cogito e do sentido unívoco da verdade, a ponto de transformá-la numa ideologia indefensável diante de outros saberes (p. 102). A metafísica os submete ao argumento da parcialidade em nome da própria razão. Entretanto, a razão moderna se apoia no modelo das ciências da natureza que a filosofia imita, e em torno do qual procura sedimentar a verdade da metafísica no Espírito.

Ora, postular a verdade universal no contexto da modernidade não se mostraria tão arriscada quanto a falta dela, uma vez que se constata que a crítica da metafísica se destina àquilo que se coloca fora de seu campo de conhecimento e de seu aparato epistemológico? E mais, se se deslocado o problema do estatuto da metafísica para um lugar eminentemente ontológico, mais do que epistemológico (do conhecimento) do kantismo, restaria ainda por indagar se ao invés de pretender banir a violência do real, como aprouve à filosofia e, concretamente, a metafísica moderna calcada na liberdade e na autonomia, não haveria uma maneira de se pensar (outra)mente, isto é, com outras mentes a contemporaneidade (VIVEIROS DE CASTRO, 2015, p. 25) de modo a abandonar tanto a especulação do idealismo transcendental de outrora, como as simplificações das ciências das natureza? E que se esta situação permitisse ao mesmo tempo lançar a metafísica para além desse tempo/lugar das suspeições levantadas pelos céticos contra os fundamentos? Eis que essas questões acompanharão nossa reflexão, pois se trata de focar a investigação na perspectiva de uma metafísica pós-metafísica tendo em vista o paradoxo que a move e a nutre, já que a justificativa para se conceber uma metafísica pós-metafísica só se erige em torno da intriga entre transcendência e imanência que, por sua vez, está enraizada antes na existência do que na essência.

\subsection{O imaginário e a metáfora na metafísica}

A fim de se poder matizar as questões postas pela contemporaneidade à filosofia, cabe elucidar o imaginário que retroalimenta o binômio violência/metafísica em busca de situar 
melhor a intenção que atravessa essa investigação. Há de se ter presente que, do ponto de vista histórico-filosófico, aprouve ao filósofo, ambientado na tradição grega, eleger como "fio de ouro" dessa tessitura a positividade da Metafisica em função da metáfora da visão (LÉVINAS, 1987, p. 207) e propugnar o metarrelato da razão como expressão do sentido último do que está para além do sensível. Com isso visava-se assegurar a unificação do sentido contra a possibilidade da dicotomia, da ruptura ou da cisão inconciliável dos polos da existência. Essa tendência do esfacelamento, por sua vez, fora associada à imanência, à história, à natureza, sendo que essas expressavam a negatividade [do real] pelo fato de encontrarem-se ligadas ao que é da ordem do mundano em oposição à transcendência identificada àquilo que está para além da physis.

Diante desse desafio, via de regra, a filosofia inspirada no "amor à sabedoria" sob o influxo de Parmênides, afirmara o fundamento inconcussum no Logos theoréticos (LÉVINAS, 1997, p. 166); na Razão, no Uno, no Ser, no Belo e no Bem, isto é, nos Universais como modos de representar e tematizar o real e de assegurar o sentido para além de toda dúvida que brota da mutação da história e da temporalidade (LÉVINAS, 1997, p. 180; p. 235). Esses universais foram associados, pela tradição ocidental moderna, ao Espírito. Este, por sua vez, como arché se erigia, como maneira de pôr em questão aquilo que seria da ordem da desordem, isto é, da ordem do caos, do anárquico, do disforme, enquanto esses últimos solapavam a verdade expondo o real à confusão e ao duvidoso. Isso se deve ao fato de o neoplatonismo ter sido praticado, desde a modernidade socrática, ancorada na certeza da consciência, na vida interior ou no Espírito em detrimento da exterioridade (matéria), a considerar como passível de engano e de inconsistência, tanto o Elemental como a mutação da physis aos quais os pré-socráticos, especialmente Heráclito, atribuíam o fundamento sem fundamento do real (LÉVINAS, 1997a, p. 181).

Coube ainda ao protagonismo do filósofo pós-socrático, como autêntico metafísico da alma (LÉVINAS, 1987, p. 55), a tarefa de denunciar o non-sens (LÉVINAS, 2002, p. 158) associando-o ao pathos, bem como de argumentar contra a desrazão e contra a ilógica subjacente a tudo aquilo que se afasta do Nôus. Nessa ótica, o pathos considerado como sendo da ordem da tese doxica fora imediatamente atribuído ao engano e à produção equivocada do incerto e do mutante, seja em seu caráter físico, sensível, seja em sua dimensão moral e, por antonomásia, como realidade social e política. Fora atribuída, portanto, à sensibilidade a responsabilidade pela violência, pela guerra e pelo mal infinito que atravessa a história e a cultura. E o desconforto em relação ao que julgara ser da ordem da causalidade científico- 
metafísico da violência, levara-o a exorcizar tudo aquilo que estivesse ligado ao duvidoso, cuja origem encontrara-se enraizada no reino do material e do corpóreo.

Nessa perspectiva, a metafísica se revelara antagônica à violência, da mesma forma em que se contrapunha ao mundo sensível e de sua estrutura causa/efeito do mal físico, moral e espiritual. Somam-se a isso os motivos de atribuir ao Espírito a força da metafísica para enfrentar a violência daquele, uma vez que, apoiada na positividade do Espírito, não se visava apenas combater a negatividade do mundo, do corpo, da carne, do tempo etc., mas de integrálos ou de iluminá-los referindo-os ao Logos e à razão (LÉVINAS, 1997a, p. 114). Dessa forma, ter-se-ia de submetê-los à unidade da evidência com o objetivo de libertar o real daquilo que está sob o domínio das sombras, da falta, do erro, identificando-os à negatividade do sensível a ser suprassumido no Espírito absoluto (LÉVINAS, 1997a, p. 113).

Em suma, a filosofia como história da metafísica desde seus primórdios até os dias de hoje afirmara que a inteligibilidade, a objetivação e mesmo a tematização eram as únicas fontes do sentido (LÉVINAS, 1987, p. 45). E no horizonte dessa metafisica do objeto, tanto Deus, o mundo e a humanidade coincidiam num ponto: foram deduzidos como o incondicionado, a partir desse objeto, por um movimento de fundação ou de condicionamento (LÉVINAS, 1987, p. 45). Contudo, a partir dessa visão domesticada, beirando o risco de resvalar numa postura maniqueísta, formatada segundo o ideal do Logos, do Espírito, em detrimento do pathos, do afeto, da carne, na natureza, etc., evidentemente, a metafísica se afirmara com uma dupla função no cenário da filosofia: uma epistemológica, com a intenção de questionar a irracionalidade ou a "violência do mal" por meio da verdade, do conhecimento objetivo e, outra, de corte fenomenológico-prático, com o objetivo de pôr em questão o "mal da violência" por meio da "suspensão de juízo" contra a ideia de que o sentido está enraizado no mundo, na empiria e na sensibilidade. Não é à toa que a primeira frase da Metafísica de Aristóteles, "todos os homens aspiram por natureza ao conhecimento", continua a inspirar seus defensores contra qualquer tipo de filosofia empírica, seja ela antiga ou nova, que tenha se tornado desdenhosa do intelecto (LÉVINAS, 1997a, p. 24-25). E se é verdade que o pensamento metafísico aristotélico se caracteriza por um substancialismo, uma vez que a substância delineia a estrutura última e íntima do ser, "a tentativa de resguardar o homem entre as coisas graças ao avanço das ciências exatas e das ciências humanas, não abalou a prioridade lógica e gramatical do substantivo" (LÉVINAS, 1997a, p. 74).

De qualquer forma, se é verdade que Aristóteles foi o primeiro a formalizar a pretensão científica e intelectual da metafísica, há de se ter presente que o arquétipo desse 
pensamento que atravessa a história da civilização ocidental, e que a induz a fazer uma contínua repetição da filosofia, segundo o sentido eminentemente filosófico do termo, está ancorado na célebre alegoria da caverna, de Platão, acompanhado do discurso silencioso da alma com ela mesma (LÉVINAS, 1987, p. 55). Seja como for, de outro modo, bem no âmago da linguagem e da sociabilidade realizada pela Política, a violência não deixa de expor a contradição contida na própria Metafísica, como assinala o filósofo lituano Emmanuel Lévinas:

\begin{abstract}
O diálogo, desde Platão, é um elemento da filosofia. Com efeito, é ao falar que a violência de cada um se eleva ao universal e, no entanto, por meio da qual, enquanto violência, ela é superada. E a filosofia procura de todo modo evitar a violência [...] E no caso da política, a universalidade na qual toda violência deve se absorver, no Estado homogêneo através do inevitável recurso à Administração que pode somente assegurar a identidade das pessoas, não é considerada como fonte de uma nova opressão. Entretanto, pode-se falar de opressão mesmo num Estado perfeitamente justo, precisamente porque a relação do Eu com a universalidade que a reconhece e a define, passa inevitavelmente por uma Administração. (LÉVINAS, 1987, p. 29).
\end{abstract}

Tendo em vista, portanto, o irrenunciável paradoxo ou a ambiguidade do real do qual não escapa sequer a Metafísica, trata-se de voltar-nos à questão de fundo, assegurando uma exposição que mais se aproxime do estatuto de uma "verdade perseguida" do que a de reforçar a ideia de uma apologética da Razão sobre a qual se calca a pretensão da Metafísica tal como fora propugnada por Platão e Aristóteles (LÉVINAS, 1997, p. 25), extensiva à modernidade de Kant a Hegel.

Ao contrário do paradigma da contemplação ou do sobrevoo do real, subjacente ao seu edifício, constata-se que "a filosofia não pode se distanciar dos truísmos e das questões de caráter sincrônico que atravessam de ponta a ponta a existência humana” (MERLEAUPONTY, 1994, p. 20). Afinal, esta se vê afetada na pele e, continuamente, tocada por essa realidade da existência de modo a ter-se de vincular a filosofia à vida da qual não se distancia, se é verdade que ela não visa reduzir-se a um sistema abstrato, conceptualista e intangível pela ambiência humana. A imbricação entre elas ocorre à flor da pele, isto é, na extensão do contato ou nesse corpo a corpo instaurado entre ambas graças à imediação do pathos, da qual não se pode retirar uma vez que a verdade não se encontra na profundidade e na verticalidade dos fundamentos, mas sim na horizontalidade da geografia ou na superfície daquilo que está colado à existência que é interrompida e recomeçada em sua extensão infinita graças às relações que a envolvem no contato com a exterioridade do outro, do mundo e do sagrado. 


\section{A VIRAGEM FENOMENOLÓGICA DA FILOSOFIA E SEU CARÁTER ANTIMETAFÍSICO}

Dada, porém, a complexidade da tensão entre metafísica e violência em função da patética, isto é, da empatia que envolve o real, isso não nos exime de ter de circunscrever a reflexão a uma determinada etapa de seu pensamento. Com isso se pretende evitar de incorrer nos mesmos vícios das contraposições e respostas genéricas, dos discursos apressados que, aliás, são a base da crítica à metafísica clássica inaugurada na contemporaneidade pela Fenomenologia de Edmund Husserl. Primeiro, porque o filósofo alemão atentou para a urgência de um novo criticismo que fosse capaz de manter a filosofia vigilante e preocupada com a presença, com o ser e a satisfação, contra a visão do bom senso e da evidência advinda da pesquisa científica e pautada em seu método empírico-formal (LÉVINAS, 1997b, p. 137). E mais, sob o signo do fim criticista da metafísica, Husserl anunciava uma filosofia distinta da ciência e o fim de certa racionalidade da filosofia que não pensa além de suas conveniências (BENOIST, 2005, p. 124); momento caracterizado pela denúncia da ilusão transcendental e de certa malícia radical na boa-fé do conhecimento, malícia numa razão porquanto "inocente de todo sofisma e que Husserl chamava ingenuidade" (LÉVINAS, 1997b, p. 139).

Diante da novidade do filosofar do mestre, Lévinas chama atenção para a novidade que a fenomenologia trazia para a questão metafísica.

\footnotetext{
Em sua fenomenologia [de Husserl] à qual o pensamento crítico conduz, isso equivale a denunciar o olhar dirigido sobre o ser, no seu próprio aparecer, como uma maneira para o objeto, na qual se absorve de boa-fé o olhar inocente, de tapar este olhar, como se as formas plásticas do objeto que se delineia à sua vista se abaixassem sobre os olhos à guisa de pálpebras: os olhos perderiam o mundo ao olhar sobre as coisas. As faculdades de intuição nas quais participa todo o corpo, os órgãos da vida em relação com o exterior seriam precisamente o que obstrui a vista. Cegamente, é contra isto que se invoca hoje uma racionalidade fenomenológica: racionalidade nova da consciência reduzida e constituinte em que o aparecer e o ser coincidem. (LÉVINAS, 2002, p. 158-159.)
}

Ao utilizar a metáfora da construção e do "abandono de seus andaimes" e do risco que isso supõe de se permanecer no "mundo das ideias", Husserl propugnava voltar-se a coisa mesma, isto é, ao fenômeno tal como ele se dá nesse intermédio de sentido entre a intencionalidade e a experiência vivida segundo a estrutura noese/noemática. Desse modo postulava, com a fenomenologia, um novo saber vivido que permitia transitar da base ao 
telhado, poder subir e descer, ir de cima a baixo na construção sem comprometer a integralidade do pensamento como evento da consciência em suas multiformes dimensões.

\begin{abstract}
Os andaimes utilizados pelas construções científicas nunca podem ser descartados se não quisermos perder de vista o sentido dos edifícios. As ideias que transcendem a consciência não se separam de sua gênese; da consciência marcada de maneira indelével pela temporalidade. Apesar do seu intelectualismo e de sua certeza com relação à excelência do Ocidente, Husserl terá questionado o privilégio platônico, até então incontestado, de um continente que se considerava no direito de colonizar o mundo. (LÉVINAS, 1976, p. 406).
\end{abstract}

Por outro lado, embora se reconheça o ineditismo da epoché, urge avançar para além da novidade do método. Ora, a fenomenologia também acabara refém dos limites da metafísica dos quais almejava distanciar-se. Ao erigir o Ego transcendental e seus congêneres, isto é, a intencionalidade, a intuição e a consciência querigmática à condição do sentido do fenômeno, Husserl acabou por identificar a Fenomenologia como Filosofia Primeira (BENOIST, 2005, p. 121). Pretendia com isso garantir seu estatuto eidético como ciência universal, contra a acusação de ser identificada apenas a mais uma variação da Doxa, não tanto por colocar acento nos estados vividos da consciência, mas por decretar o caráter apodítico da fenomenologia (BENOIST, 2005, p. 249). Do mesmo modo, ela opunha-se ao cientificismo e ao sensualismo das ciências humanas reinantes durante o século XIX. E embora remeta seu objeto ao "mundo vivido", jamais entregue ao reducionismo da verdade de objeto, o evento encontrava sua justificativa na intuição ou na Presença do objeto à consciência (LÉVINAS, 1997a, p. 166).

Ao reivindicar para si o estatuto de filosofia primeira, a fenomenologia acabara vítima da emboscada da violência que visava combater e associara-se a uma "Metafísica da presença" (DERRIDA, 1996, p. 78). A redução transcendental referia o sentido à atividade da consciência para a qual tudo se torna transparente segundo a intuição, graças à estrutura noemática. Afinal, quando Husserl se distanciava do próprio fenômeno para ater-se à redução eidética na consciência como Espírito, reeditava-se, de outra maneira, a metafísica, por ela conceder primazia à objetividade sobre a experiência vivida (BENOIST, 2005, p. 85). Deslocando o problema da metafísica da questão clássica do fundamento ao problema contemporâneo do sentido, assegurava-se a significação da experiência na consciência, confiando, portanto, em última instância, ao Ego transcendental a função de assegurar o sentido da subjetividade, da relação intersubjetiva e da vida objetivamente considerada em função das reduções eidéticas. 


\begin{abstract}
De ora em diante, todo ser deve ser compreendido na sua gênese a partir deste aparecer privilegiado na consciência transcendental, partir desse fenômeno-ser, desta presença ou deste presente-vivo dado à intuição em que todo transbordamento da presença real fica assinalado, medido e descrito. Privilégio da presença que Derrida põe precisamente em questão [...] A própria possibilidade da plenitude de presença é contestada. Esta seria sempre adiada, sempre simplesmente indica no querer dizer que, para Husserl, se referia inteiramente à plenitude intuitiva. É a crítica mais radical da filosofia do ser para a qual a ilusão transcendental começa no nível do imediato. (LÉVINAS, 2002, p. 159).
\end{abstract}

Nesse caso, mormente se possa evidenciar o valor da fenomenologia contra a reificação do real praticado pela metafísica clássica, não se pode olvidar que, ao conceder primazia à intuição e à intencionalidade, a fenomenologia não tenha conseguido livrar-se da crítica à metafísica da presença e, consequentemente, do caráter violento que essa contém (BENOIST, 2005, p. 157). Enfim, mesmo colocando ênfase no evento da consciência em detrimento da objetividade, subjaz ao estatuto da fenomenologia o paradigma transcendental em que o Ego se erige como instância crítica sobre todas as outras reduções e relações transcendentais, despovoando o mundo vivido de sua anterioridade à consciência.

Ora, a metafísica da presença não leva em conta a diferença intrínseca ao evento da consciência (DERRIDA, 1996, p. 98). Isso, certamente, permitiria introduzir não apenas o criticismo ao transcendental da fenomenologia, mas, sobretudo, compreender que o mundo vivido da consciência é antecedido pela própria vida ontologicamente pensada. Por isso ela não pode ser submetida à violência da redução transcendental, uma vez que a vida está na gênese da consciência transcendental e das demais reduções intersubjetiva e objetiva. Eis que a ontologia tem como pretensão evadir-se desse equívoco e desse reducionismo e violência da fenomenologia.

\title{
4 ONTOLOGIA VERSUS METAFÍSICA DE OUTRO MODO QUE SER
}

Levando-se em conta, pois, a primazia dada à "compreensão" e à "linguagem" do ser contra os limites da nova epistemologia da consciência transcendental, tomamos como referencial, para os próximos passos da reflexão, o impacto da viragem ontológica sobre a metafísica, introduzida no bojo da filosofia ocidental por Martin Heidegger. E, apesar de reconhecer o valor da crítica da ontologia à fenomenologia, Lévinas acusa esta de não se reproduzir senão como um "outro modo de ser" da metafísica da presença e de recair no problema do mal infinito ao qual se referia Kant. Pois, como recorda o filósofo franco-lituano: 
Apesar do realismo da destruição da metafísica que se cumpre no pensamento heideggeriano do ser, é, por sua vez, a metafísica ocidental que permanece sendo o solo sobre o qual esse pensamento retorna ou labora. É o ser, o esse, em sua essência, em sua perseverança, em seu evento, que em toda essa história da filosofia, história de um saber, constitui o último referencial do sentido e do pensamento. (LÉVINAS, 1994, p. 138).

Em função desse confronto, trata-se de retomarmos algumas das interpelações que advêm especialmente do pensamento de Jacques Derrida e Emmanuel Lévinas dirigidas à ontologia, seja pelo fato de ambos terem entabulado uma profícua discussão em torno da temática da transcendência ontológica e da acusação de que ela se constitua numa outra forma filosófica de representação e violência, seja por terem fecundado a questão da metafísica trazendo, respectivamente, para dentro da filosofia, a alteridade e a diferença em contraposição ao saber ontológico sempre referido ao horizonte do Ser. Delineia-se, portanto, especialmente com a filosofia do Rosto, a possibilidade de propugnar um pensamento para além do Ser, cujo estatuto se aproxima de uma paradoxal metafísica pós-metafísica que perseguimos nesta exposição a fim de tentar fugir da aporia da violência implícita à metafísica calcada na tese dóxica da razão.

\footnotetext{
A relação com o rosto, com o outro absolutamente outro que eu não poderia conter, com o outro, nesse sentido, infinito é, no entanto, a minha ideia, um comércio. Mas a relação mantém-se sem violência - na paz com essa alteridade absoluta. A resistência do outro não me faz violência, não age negativamente, tem uma estrutura positiva: ética. (LÉVINAS, 1988, p. 176).
}

Retomando, ainda que de maneira breve, o percurso da filosofia em função da viragem ontológica, há de se rememorar que na obra Ser e tempo, Martin Heidegger se revela como um precursor da reação à repetição da filosofia que se processa como outra maneira de metafísica. Isso se deve à ênfase que a ontologia destina à crítica ao que ela denominava de predominância de uma ciência ôntica no seio da filosofia ocidental. Embora o saber ôntico tenha manifestado sua diversidade de formas, há um elemento estruturante que os perpassa (LÉVINAS, 1997a, p. 113). Todos eles estão edificados e inspirados no afã da representação (LÉVINAS, 1997a, p. 113), da tematização e do historicismo amparados por um discurso rigoroso do Espírito e de sua conceptualização intelectualista (LÉVINAS, 1997a, p. 113). Em função disso, a ontologia se declarava avessa ao discurso ôntico. $\mathrm{O}$ fracasso da ciência dos entes, segundo o filósofo alemão, se deve ao fato de o Ser e sua linguagem terem sido esquecidos pela filosofia ocidental desde Sócrates até Husserl, em função da valorização do 
conhecimento objetivo e da primazia da epistemologia sobre a ontologia.

De acordo com a leitura de Lévinas, para a perspectiva heideggeriana tanto o saber quanto a linguagem (ôntica) foram concebidos segundo a ideia do Ente, abstraindo-se, ideologicamente, a diferença ontológica ser e ente a qual assegurava-se a novidade intangível do Ser (LÉVINAS, 2002, p. 171). Portanto, negando-se a diferença ontológica, o pensamento filosófico recaía no absurdo de opor-se à verdade do Ser e, por antonomásia, contra o ser humano, contra o mundo e contra a o sagrado. Ora, por um lado, o Ser não pode ser apreendido segundo a representação e a tematização pelo saber, porque de fato o Ser não é substantivo, mas verbo, isto é, verbalidade do Ec-xistir; por outro, imerso nessa tentativa insistente de objetivação do ser, especialmente, o ser humano, o Dasein, que encarna o paradoxo da diferença ontológica porquanto reúne em si a condição de ente e de ser que se pergunta pelo ser, acaba imerso na queda ou numa existência inautêntica. Ele deixa de se referir ao Neutro para eleger o Ser como fundamento sem fundamento de seu ser humano.

Nessa perspectiva, a ontologia visava debelar o engodo e a enfermidade da metafísica, isto é, pretendia livrar-nos da do-ente reificação da existência e da patológica pretensão de a sintaxe da metafísica unificar, por meio do conhecimento objetivo e da língua que decorre desse conhecimento, o mundo, o homem e o sagrado. Contra isso era necessário, segundo Heidegger, voltar aos poetas representados pelos pré-socráticos para dar-se ouvido à voz e à linguagem genuína do Ser, tal como procedem os autênticos filósofos da ontologia, contra o platonismo da filosofia ocidental. A ontologia decretava, assim, uma ruptura com a metafísica, de modo a opor-se tenazmente à violência do saber, do existir e do falar que aquela produz, porquanto ela está calcada na Razão. Segundo Heidegger, a maneira de tirar o ser do esquecimento constituía-se como um autêntico projeto filosófico-existencial inseparável da escatologia do Ser, respectivamente, como declaração do fim da antropologia, da onto-teologia e da cosmologia clássica, ao mesmo tempo em que punha no centro da filosofia a facticidade e a ecceidade da Ec-xistência. Desse modo, trazia para dentro da Existência aquilo que a metafísica clássica havia atribuído à causa do mal, a saber, o pathos, a sensibilidade, a mundaneidade e a ambiência do ser-no-mundo (LÉVINAS, 1997b, p. 110).

Essa adesão positiva ao mundo, ao contexto e à temporalidade do ser, fora enaltecida pela ontologia como modo de descontaminar a epistemologia da filosofia ocidental e da maneira como concebera a negatividade do real até então sob a égide do distanciamento e da apreensão do ser como objeto da razão. Com isso, dava-se vazão à "compreensão" do ser graças ao pertencimento ao Ser e à linguagem poética, do qual a existência e a verdade do ser 
não podem se desvincular, com o risco de ceder à ideologia e à queda da humanidade numa existência inautêntica (LÉVINAS, 1997b, p. 118). A existência humana doravante passara a ser vivida de maneira a conciliar uma interpretação e uma hermenêutica de si, imersa no ser, porque existência jogada (derrelição), presente e projetada na temporalização da temporalidade do ser e na maneira de habitar a morada do ser pela linguagem da qual não se desfaz e não pode ser tematizada a fim de não se resvalar na obliteração do Ser (LÉVINAS, 1997b, p. 119). Daí que a interpretação da existência, no contato e no confronto com as coisas dadas no ser-no-mundo, é inseparável da linguagem do ser e de sua verbalidade. Por isso a insistência da ontologia em primeiro evadir-se das malhas da metafísica por uma Ontologia fundamental e, posteriormente, em fazê-la avançar por uma reabilitação de sua linguagem poética (RICOEUR, 2011, p. 97). Seu estatuto se mostrara coetâneo daquela do dom, da generosidade do ser e, portanto, alheia à linguagem demonstrativa, técnica e científica que se distanciam da linguagem primeva do Ser (RICOEUR, 2011, p. 95).

No entanto, mesmo no caso da crítica ontológica à história que a precede, há de se atentar para o problema metafísico de fundo não solucionado. A reflexão filosófica

[...] não pode contentar-se com a reflexão sobre si ou sobre a existência porque essa dá-nos apenas o relato da aventura pessoal, da alma privada, que retorna incessantemente a si mesma, até quando parece fugir de si, recorda o filósofo lituano. A fim de escapar dos limites da ontologia urge ir para fora do Ser, de modo que "o humano só se oferece numa relação que não seja poder sobre si nem poder sobre a morte como última das possibilidades humanas. (LÉVINAS, 1997a, p. 33).

A ruptura, portanto, da violência, segundo Lévinas, não está apenas em tirar o ser do esquecimento e de reabilitar a linguagem poética qual modo de abandonar a objetivação propalada pela ôntica, mas isso exigiria dar um passo radical para fora do Ser, isto é, deixar de referir o outro à compreensão ontológica e à linguagem poética do Ser, como se outrem fosse resultado da generosidade do ser.

Isso só acontece na temporalidade u-tópica do encontro com o dom do outro cujo evento acontece no face a face com o Rosto humano, fora das malhas ou da referência ao Ser. Nessa perspectiva somente o Rosto de outrem pode interromper a violência velada da aparente generosidade do ser (LÉVINAS, 1997a, p. 246). E o nome concreto do mal do ser diz respeito à violência ética feita ao outro humano. Esse se vê sempre reduzido ao contexto cultural, ao seu lugar no mundo, cuja mortalidade não afeta o Existir do Ser e sai da eternidade de ser para além da morte do rosto mortal. Contra isso, afirma Lévinas: “Outrem é 
o único ente cuja negação não pode anunciar-se senão como total: um homicídio. Outrem é o único ser que posso querer matar" (LÉVINAS, 1997a, p. 31).

Essa interrupção do Ser se deve ao fato de que, na relação com o outro, o eu o interpele pelo fato de o Rosto irromper diante dele da mesma forma como Ele, o Rosto, suscita no sujeito uma saudação, um vocativo (diante do desconhecido, inesperado, exterioridade), isto é, desperta-o à invocação e à expressão (LÉVINAS, 1997a, p. 28) antes mesmo que ele, como Dasein, possa compreender o outro em função da abertura do ser, das possibilidades dadas pelo horizonte do Ser, ou mesmo que ele possa reconhecer-se estando lado a lado com o outro como se outrem fosse um outro Dasein (LÉVINAS, 1997a, p. 31).

É de se esclarecer, ainda, que o movimento de evasão da ontologia não consiste em deixar o outro ser em seu ser-aí ou apenas em se admitir em ser-com-outro-no-mundo (LÉVINAS, 1997a, p. 31). Afinal, o outro enquanto Rosto jamais se adequa ao mundo uma vez que, ao falar, ele interrompe a linguagem do Ser (LÉVINAS, 1997a, p. 30). O Rosto se diz a si mesmo e se significa fora de toda significação. Ele não depende do contexto, da compreensão e, por conseguinte, não se submete às categorias do ser. Ao contrário: na ótica da ontologia, o outro acaba sempre circunscrito ao impessoal do Há e da verbalidade do Ser. Em última instância, para Lévinas, o Ser aparece associado ao Mal de Ser exatamente por se mostrar indiferente à fala do Rosto que fala, e cuja palavras o tornam diferença absoluta com relação à linguagem do Ser. Contra a violência do ser, Lévinas insiste na dinâmica que subjaz a ontologia.

O fazer-face de outrem, na sua retidão, significaria o sem-defesa como também a oposição da alteridade [...] A alteridade de outrem é a ponta extrema do "tu não cometerás homicídio" e, em mim, temor por tudo o que meu existir, apesar de sua inocência intencional, corre o risco de cometer como violência e usurpação. Risco de ocupar, desde o Da do Dasein, o lugar do outro e, assim, concretamente, de o exilar, de o jogar na condição miserável em qualquer 'terceiro' ou 'quarto' mundo, de o matar. (LÉVINAS, 1997a, p. 198)

Em suma, pelos motivos supramencionados, parece "razoável" aceitar que, se é verdade que a ontologia postulava a interrupção da "metafísica por associá-la à violência", resta ainda reconhecer que ela submete o outro ao padecimento, dada a indiferença do Ser à diferença absoluta inaugurada pelo advento do outro que clama por Justiça (LÉVINAS, 1997a, p. 30), porque o Rosto é da ordem do infinito. Esta consiste positivamente em cuidar e proteger o Rosto, isto é, em amá-lo a fim de que ele não seja violentado na vulnerabilidade de sua nudez e nem seja assassinado pela resistência ética que põe aos meus poderes pelo fato de 
se retirar constantemente do domínio do ser e de sua linguagem e me colocar na esteira do desejo do indesejável (LÉVINAS, 1997a, p. 32).

\section{PARA ALÉM DA ONTOLOGIA E DA LINGUAGEM POÉTICA DO SER}

A propósito da ontologia, Lévinas reconhece a novidade que esta havia introduzido no pensamento filosófico, sobretudo se se toma a novidade do caráter linguístico considerado como casa do ser. Ao interromper a tradição metafísica da filosofia ocidental, Heidegger tratava os fragmentos dos filósofos pré-socráticos como se fossem "versículos bíblicos" (LÉVINAS, 1987, p. 25), embora admitisse que "nossas línguas não deem conta de expressar a originalidade que a poética ontológica" visava trazer para o centro da filosofia.

\footnotetext{
Esquece-se com facilidade aquilo que Heidegger diz da sintaxe dos pré-socráticos: a associação das palavras sem articulação, longe de apresentar um estádio inferior da expressão, que ainda não atingiu a clareza e o destino de nossa língua, essa simples vizinhança, esta não-articulação exprime uma densidade já perdida em nossas línguas. (LÉVINAS, 1987, p. 25).
}

Entregue, pois, à dinâmica da auscultação do Ser, numa clara oposição ao sentido da visão, cujo significado fora evocado como metáfora do pensamento metafísico e sua pretensão de conduzir à iluminação do real, Heidegger, preocupado em reabilitar a linguagem perdida do ser, passa a insistir sobre a linguagem bucólica do pastoreio. Tratava-se da premente necessidade de obedecer à voz do Ser como escuta e cuidado do Ser contra a totalidade do Saber metafísico. Entretanto, isso dera margem para que seus opositores suspeitassem que, sub-repticiamente, a ontologia estivesse a impor aos existentes uma violência velada da poética violentar do Ser.

Primeiro porque, ao romper com a fenomenologia e sua estrutura, motivado pela oposição à "metafísica da presença" (LÉVINAS, 2002, p. 159) inseparável do Ego transcendental, Heidegger optou pela compreensão do ser seguindo a estrutura da escutaresposta que já não é mais da ordem da epistemologia da fenomenologia ou do aparecer do ser. Esta, portanto, alude a uma relação misteriosa ou quase sacralizante do Ser e seu desvelamento. Nessa esteira, a ontologia reivindicara para si a reabilitação do pensamento paradoxal, um pensamento avesso à tese dóxica da qual não escapara sequer a fenomenologia centrada no Ego transcendental. Este atesta a "idealidade como presença" (FERRARIS, 1999, p. 167-182) de uma consciência desligada ou sem-existência-no-mundo e, portanto, entregue 
à intelecção dos estados vividos pela intuição de modo a conceder primazia ao transcendentalismo (a intuição) em detrimento da experiência.

Dito de maneira mais clara, o ser como dom e a poética do ser se contrapunham ao querigma da consciência (LÉVINAS, 2011, p. 59). Não era propriamente dito a estrutura do saber apodítico, a intencionalidade, a evidência e a intuição que fundavam a verdade. Em última instância, cabia à linguagem da consciência declarar o sentido. Ora, se se reserva à linguagem a função de dizer o sentido, isso significa, entre outras possibilidades, o esvaziamento do caráter apodítico do conhecimento em detrimento da tese dóxica.

Apesar da crítica assertiva da ontologia à fenomenologia, o fato é que, ao propugnar o evento de ser na confluência do saber, do pensar e do viver, isto é, da coincidência do filosofar e do existir, graças à Existência em sua facticidade que se opõe à consciência semmundo, o pensamento paradoxal de Heidegger corria sério risco de se voltar contra sua intuição originária de retirar o ser do esquecimento. Isso se justifica porque, se a ontologia se opunha tenazmente à tese dóxica que subjaz à significação do sentido em nome da verdade do ser e, ao mesmo tempo, a concebe a partir do dom e da linguagem [poética] como sendo a especificidade do ser-no-mundo, não resta senão dar crédito à "revelação" do Ser (crer), isto é, à verdade de uma "inteligência" do ser que só se cumpre no acolhimento confiante a sua generosidade (es gibt), cuja verdade universal se desvela em função da incontestável bondade de Ser.

\begin{abstract}
Heidegger descreve assim, na sua estrutura mais formal, as articulações da visão em que a relação do sujeito com o objeto é subordinada à relação do objeto com a luz a qual não é objeto. A inteligência do ente consiste então em ir para além do ente precisamente no aberto - e em percebê-lo no horizonte do ser. Equivale a dizer que a compreensão, em Heidegger, logra alcançar a grande tradição da filosofia ocidental: compreender o ser particular é colocar-se além do particular - compreender é relacionar-se ao particular, único a existir, pelo conhecimento que é sempre conhecimento do universal. (LÉVINAS, 1997a, p. 26)
\end{abstract}

Tratava-se, com isso, de reeditar, segundo seus opositores (SLOTERDIJK, 2000, p. 33), uma forma muito velada da violência do ser por meio da domesticação dos existentes subservientes e submetidos à aparente docilidade desse dom e dessa poética do Ser. Na verdade, esses (existentes) jogados em Ser (derrelição) e projetados ao Nada a partir do horizonte do Ser e, portanto, sob a condição de uma reverência ao Ser e de uma referência ao Neutro, já não podiam se retirar desse domínio a não ser negando-se a si mesmos, comprometendo, segundo a compreensão da própria ontologia, a autenticidade da existência 
(LÉVINAS, 1997b, p. 109). Ao se desligarem da diferença fundamental ser/ente, como condição existencial do Dasein, os existentes se entregavam passivamente ao mal ôntico, e com isso se reeditava o mal metafísico que a ontologia viera colocar em questão.

Não é à toa que, ao se indispor contra a linguagem da representação da metafísica, com o propósito de reabilitar a linguística do discurso da ontologia, vem à tona uma contradição subjacente ao projeto heideggeriano. Esta se mostra no fato de que nem mesmo a ontologia se desvencilhou da lógica do discurso e da pretensão de articular o Ser em torno da razão e da natureza, uma vez que essas categorias aparecem associadas à "narrativa da clareira do Ser" (SLOTERDIJK, 2000, p. 35). Certamente é por esse motivo a constatação, do próprio Heidegger, de que a poética do Ser encontrara dificuldade em afirmar o sentido na pretensa desarticulação da sintaxe grega, uma vez que a Iluminação e o extasis da Metafísica continuaram sendo a referência à linguagem sem que a poética do Ser pudesse, de fato, se emancipar do imaginário violento da metafísica e de uma "história social das domesticações" (SLOTERDIJK, 2000, p. 33).

Em suma, ao reabilitar a ontologia haveria de se arcar com as consequências do impacto que ela exerce sobre os existentes, uma vez que eles estão destinados a se colocarem a serviço da manifestação e de emprestarem a boca para a poética do Ser. Pois, se por um lado parece que eles readquirem a dignidade das Humanitas se comparada ao humanismo moderno da razão sem linguagem, por outro o ser parece domesticar e promover a docilidade dos corpos em função da ontologização da existência. Assim, a ontologia parece comprometer tanto a unicidade dos existentes diante do impessoal do Ser quanto a alteridade de outrem irredutível à poética do ser. Afinal, esta não se significa a partir do contexto do ser-com-ooutro (Miternandersein) da ontologia. Antes, a significação só se dá na própria significância, isto é, no poder falar de um Rosto e, assim, interromper a língua e o discurso e desestabilizar a sintaxe propugnada pelo Ser, por sua linguagem e pela poética do Ser que se mostra indiferente à diferença de outrem.

Eis, pois, que o contato, a proximidade do Rosto, interrompe a poética do ser com sua palavra profética. Assim, a palavra que vem do Rosto, cujo sentido se refere a um poema da sensação (LÉVINAS, 2014, p. 63) no contato com outrem, e que continua viva no Livro, isto é, que ao se manter em sua estrutura anárquica, pode ser reabilitada constantemente na ética ou na escuta do próximo/estrangeiro (LÉVINAS, 1997a, p. 191), e passa a ser a ótica e a via real de evadir-se do Mal do Ser. Essa palavra que advém do Rosto e que diz: não matarás, ou que, de maneira positiva, coloca o desejo de outro graças ao interpeles qual um aperto de mão 
entre o eu e outrem (LÉVINAS, 2011, p. 36), cuja pele acariciada (LÉVINAS, 2011, p. 107) interpela e inaugura uma experiência do amor/justiça como amor sem concupiscência. Somente esse amor pode colocar radicalmente em questão o caráter ainda metafísico e injusto da poética da ontologia.

\section{O PARADOXO DE UMA METAFÍSICA PÓS-METAFÍSICA}

É evidente, neste estágio da reflexão em que já se delineia o confronto do pensamento da alteridade com a ontologia, de modo a evidenciar as contradições de seu projeto pósmetafísico bem como a de submetê-la à crítica pós-ontológica da violência contra o outro, que ela merece uma melhor matização nos próximos passos. Afinal, urge saber se uma filosofia do outro, tal como propugna, especialmente Emmanuel Lévinas não incorreria noutro tipo de violência do saber, que se manifestaria tão arriscado quanto o da ontologia e que, no entanto, aquele filósofo pretendeu dissuadir-nos.

No contexto da indagação, urge focar a atenção sobre o consagrado escrito Metafísica e violência, do filósofo francês Jacques Derrida, como referência para pensar a metafísica para fora de ser. Diante do embate de Lévinas contra Heidegger, Derrida se propusera a trazer à baila, como parece bem apontar a sequência do título de seu escrito (DERRIDA, 1967, p.117), uma interpelação sobre a referida iteração, embora também se indague se a paradoxal expressão de uma metafísica pós-metafísica propugnada por Lévinas, que já passou pelo crivo da compreensão e da linguagem, respectivamente, associadas à epistemologia e à ontologia fundamental, de fato não seria tão violenta quanto a violência da metafísica clássica. Assim, a retomada do pensamento da alteridade em torno da ética possibilitará avançar na matização da problemática abordada como fruto de um esforço filosófico redobrado de matizar seu pensamento em função da primazia que concede ao Outro sobre o Ser, a ponto de poder pensar o Outro modo que Ser da Metafísica.

Eis, portanto, que nos deparamos com um "paradoxo salutar" a partir da relação com o outro. Ele se instala no bojo da filosofia contemporânea de modo que "pensar a violência" significa ter de "pensá-la já como pensamento 'da' violência e 'com' a violência" para além dela, evidentemente, não em vista de legitimá-la, mas sem abstrair-se dela, levá-la a sério como problema filosófico candente do qual nenhuma metafísica poder-se-ia absolver em nome de seus princípios para além do bem e do mal. Isso, porém, deve suscitar, no caráter epistemológico do pensamento filosófico, a disposição de exercitar aquela atitude denominada 
pela fenomenologia epoché, isto é, de "colocar entre parênteses" ou de suspeitar dos pressupostos de um pensamento que se queira harmônico ou positivo, em detrimento da negatividade e da ambivalência (MERLEAU-PONTY, 1965, p. 196), do qual não se pode distanciar sob condição de pôr-se em xeque o estatuto da verdade perseguida a ser seguida desde o mundo dos mortais diante do outro.

Significa, outrossim, cultivar a atitude positiva de exercitar o paradoxo introduzido pelo contato com o Rosto como condição crítica de um filosofar que, portanto, se enraíza no "paradoxo humano", bem como aceitar considerar essa contradição como fonte que subjaz e retroalimenta a filosofia enquanto pensamento da diferença para além de uma "Metafísica da presença" (DERRIDA, 1996, p.78). Isso se deve ao fato de que a relação com outrem não se funda na certeza e na lógica da razão dóxica, embora não se possa negar que subjaz à relação uma lógica da ética e da justiça que são extremamente exigentes. Esse paradoxo se sustenta em função da novidade que o Rosto introduz na relação por meio de sua apresentação, que no momento em que se faz presente, já se tornou ausência, graças aos vestígios do infinito (LÉVINAS, 1997a, p. 89). Do mesmo modo, o rosto próximo é absolutamente extraterritorial. Sua nudez de rosto "é um desenraizamento do contexto do mundo, do mundo que significa como contexto" (LÉVINAS, 1997a, p. 89). Não se situa em lugar algum porque vem de alhures. Essa chegada se diz como comunicação e expressão pré-originais de um "passado imemorial” que, tendo vindo, já passou (LÉVINAS, 1997a, p. 89).

Desse modo, a filosofia que se queira como um pensamento do paradoxo se percebe, concretamente, imersa no evento de ser inaugurado pelo advento ou pela proximidade do próximo (LÉVINAS, 2011, p. 34). Esse contato com outrem evoca, seja a bondade que se plasma nas relações humanas, na vida pública e na política, nas religiões e nas culturas, etc., seja a injustiça, a banalidade do mal e a indiferença que se inscreve na história e no mundo (da vida). Desse modo, a ambiguidade que emerge do drama da relação com outrem desponta como terreno fértil da condição incerta e da impossibilidade para a humanidade do humano, se comparada com a certeza do sujeito advinda da razão e do transcendentalismo. Aliás, o labor filosófico se apoia no princípio do cogito como ponto de partida para a arte de filosofar. Ao contrário, convencida pela incerteza ou por ter-se de aguardar o porvir de outrem que não se submete à razão, a filosofia do outro se opõe ao saber de sobrevoo, à especulação e à apatia diante do real (LÉVINAS, 1997a, p. 115). As questões viscerais ou as vicissitudes humanas não podem ser pensadas fora da relação com outrem, e ela nos remete imediatamente às questões da violência, do sofrimento humano e da morte dos outros. Isso leva a pensar que a 
própria realidade da violência contempla em si um paradoxo graças ao Rosto; diante dele, a filosofia não pode se furtar ou eliminar de seu terreno a questão hiperbólica da fome, da nudez, da vulnerabilidade de outrem sob condição de se contradizer radicalmente, como se ela mesma não fosse esse pensamento paradoxal.

Trata-se, pois, de um lado, de a filosofia se conceber a serviço da bondade que se expressa na humanidade para outrem e de reconhecer que, apesar desse si dessa humanidade, o caráter hiperbólico que se manifesta nela se deve ao excesso do Bem advindo do rastro do Rosto deixado naquilo que é próprio da relação com outrem, da qual ninguém está autorizado a abstrair-se. Trata-se da relação com aquele que se revela ao mesmo tempo "próximo e distante" (LÉVINAS, 1997a, p. 191) e, por isso mesmo, "desenraizado, apátrida, não habitante, exposto ao frio e aos calores das estações de maneira que ele me incumbe" (LÉVINAS, 2011, p. 109). A relação subsiste nessa situação do contato que, em última análise, constitui a humanidade do homem. Essa metáfora do ser alterado e expulso de si como condição genuinamente humana, mais do que mera figura de linguagem, advém do próprio encontro com um Rosto humano do qual a filosofia não pode perder o contato com o risco de se perder nas divagações metafísicas assépticas e inodoras. Pois é na proximidade da qual ninguém está autorizado a pensar antes de sentir/agir, isto é, no embate e na relação com um Rosto humano próximo e longínquo, que se cumpre o juízo da história ao mesmo tempo em que se inaugura para a humanidade o porvir de outrem (LÉVINAS, 2011, p. 33). Nesse caso, sem retirar-se da esfera da relação ética subsistente com o outro, compete à filosofia se instituir mais como "testemunho da justiça" (LÉVINAS, 2011, p. 157) do que em um discurso lógico da transcendência ou do tempo enquanto sincronia do passado, do presente e do futuro em torno da manifestação do Ser (LÉVINAS, 1997b, p. 109). Contra a violência surda da perseverança no ser, a filosofia pode erigir-se como uma metafísica da paz ao reverso da metafísica do inter-esse (LÉVINAS, 2011, p. 26).

Paz diferente da simples unidade do diverso sob a síntese que o integra; paz como relação com o outro na sua alteridade de absoluto, reconhecimento no indivíduo da unicidade da pessoa. Amor como operação lógica. (LÉVINAS, 1997a, p. 246-247).

Por outro lado, graças a essa constatação, urge à filosofia, compreendida como modo de existir do testemunho diante de outrem, a tarefa de delimitar ou de colocar medida para a relação humana tendo em vista o próprio interdizer que se interpõe na relação com o outro, o diferente. Sendo da ordem da desmedida, o Rosto põe, paradoxalmente, um interdito segundo 
o Desejo, para a própria relação pessoal, social, política etc. Afinal, sem regras, normas, justa medida - a justiça - que assegure a configuração do amor entre os homens no mundo, a filosofia correria o risco de abstrair as condições em que se trava a coexistência dos homens, a estruturação e o enraizamento cultural e histórico numa história que se queira baseada na justa medida da relação e na relação justa.

Somente a justa medida, o equilíbrio, a comparação, a pesagem, o cálculo, a tematização e a representação podem garantir que a bondade ou o amor (ético) entre os homens se cumpra de fato nas relações, nas sociedades e nas culturas. Trata-se, pois, da maneira de opor-se à violência, ao mal da injustiça presente tanto nas relações próximas como nas relações longínquas, com o próximo de meu próximo. E esse cumprimento se concretiza e se revigora na Justiça (LÉVINAS, 1997a, p. 144), de sorte que o amor necessita da justiça para se tornar justo e mensurável, e a justiça que, por sua vez, mantém certa autonomia com relação ao amor, por depender da triangulação e da socialidade da relação, não poderá se pensar sem a inspiração que a alarga, a amplia, a verticaliza, tal como sugere a geografia dos meridianos ou dos semicírculos abertos e infinitos. Essa geografia do desejo e da ética deve corresponder à sabedoria do amor, isto é, a um saber que exija que o amor se concretize na justiça social, na política e no Direito (LÉVINAS, 1997a, p. 148).

Nesse contexto vale ressaltar o ressurgimento do paradoxo do qual a metafísica não poderá imiscuir-se se não quiser cair nas antinomias da Razão que continuam a levantar suspeita sobre a doxa do racionalismo da metafísica ocidental. Ora, no nível da própria linguagem da qual a filosofia se serve para dizer o amor, já se põe a questão da medida, isto é, a preocupação em ter-se de contemplar no interior de uma sintaxe e da semântica correspondente, o Dito que se coagula na medida que é a justiça, de modo a poder delimitar o Dizer do amor no discurso sem que com isso a delimitação seja violenta. Nesse contexto, recorda Lévinas, o discurso considerado da ordem do Dito (na Justiça) fixa o Dizer da imediação da relação ética ou do amor para com outrem, embora o Dito já seja uma forma de traição do Dizer originário (do Amor).

Portanto, sem levar em conta esse paradoxo do Dizer/Dito em torno da própria linguagem, uma vez que se trata de um paradoxo intrínseco à própria experiência humana do encontro com outrem, estaríamos entregues à violência sem justificativa entre os homens. E pior: compelidos a praticá-la em nome do próprio bem (comum) ou da bondade. Ora, essa problemática se configura como um dos equívocos do pensamento do qual a Metafísica histórica não se desvencilhou e sequer as versões pós-metafísicas da filosofia contemporânea 
conseguiram equacioná-la. Essas tentativas descartam facilmente a ambiguidade incontornável que perpassa a própria linguagem do Amor/Justiça, bem como esquecem da precedência das singularidades, dos entes, sobre o Ser universal quando o ente/rosto conta como tal sem necessitar estar referido ao Ser. Ao universalizar a linguagem a partir do Ser como Logos e, consequentemente, torná-la impessoal, referindo-a ao neutro do ser, violentase a unicidade de cada um em prol da imposição da referência ao "ser do ente" como justificativa da lógica do Ser. A ontologia esquece facilmente que o "ente enquanto ente" pode assegurar um Dizer originário de sorte que ela, a ontologia, insiste na pretensão de se garantir a unidade do ente em função do horizonte indeterminado do ser e de sua linguagem ontológica.

Nessa perspectiva, querer universalizar as relações intersubjetivas, sociais e políticas, etc., por meio da razão, da linguagem ou do ser, significaria submetê-las a uma violência sem limite. Entretanto, não basta criticar tal postura entregando-se à aporia ou à antinomia ao propugnar um (amor) e negar outro (justiça) ou vice-versa, mas é preciso manter a tensão entre um "e" outro tal como anuncia e se cumpre no paradoxo humano, concebido como relação que se trava no drama do amor e da justiça graças a outrem. Em suma, se há alguma possibilidade factível de evadir-se das malhas da aporia ou das antinomias implícitas à metafísica ocidental, isso só ocorre mantendo-se a contradição entre os polos, fecundada pelo paradoxo humano em torno da proximidade do próximo em seu estrangeirismo, o qual, por sua vez, acontece graças ao que, na ótica do pensamento encarnado, Merleau-Ponty denominara de "quiasma da carnalidade do sensível" (MERLEAU-PONTY, 1965, p. 253).

Graças ao corpo a corpo da humanidade se enlaçam nessa intriga as exigências do Amor e da Justiça, e Lévinas chegará a associá-las à encarnação e à subjetividade fora do sujeito (LÉVINAS, 1997b, p. 171) como substituição (LÉVINAS, 2011, p. 142) e maternidade de outrem como gestação do outro no mesmo (LÉVINAS, 2011, p. 93). Se há lugar, portanto, para se falar da relação com outrem como sendo da ordem do trauma e até mesmo do sofrimento, isso não significa que a violência da proximidade do outro seja da natureza daquela que visa a subjugar, a destruir e a violar os direitos do eu (LÉVINAS, 2011, p. 143). Primeiro, porque é a força desse contato que cava e fere a subjetividade segundo o apelo do interpeles, e da perfuração dos ouvidos pela palavra proferida por outrem, que o sujeito se sente empoderado no desejo e na inspiração de outrem a fazer-lhe justiça contra toda injustiça da metafísica da razão e da essência. Segundo porque, no contato, a posição do sujeito é já deposição, não conatus essendi (LÉVINAS, 2011, p. 30), mas a partida da 
substituição de refém que expia a violência da própria perseguição. Daí que essa destituição é da ordem do Dizer anterior ao Dito e do discurso na qual ele teria perdido a sua violência traumática (LÉVINAS, 2011, p. 143). Por isso, se sente expulso e impelido para fora de si, em direção à Exterioridade de outrem, graças à inspiração e à respiração que o Rosto lhe põe na carne (LÉVINAS, 2011, p. 157). O sujeito assujeitado já não se compreende senão como umcorpo-para-outrem, a ponto de se dizer no acusativo como Eis-me aqui para outrem (LÉVINAS, 2011, p. 157) por conta de sua sensibilidade exposta, mais passiva do que toda passividade nessa "imediatez da paz que o incumbe" a cuidar da vulnerabilidade de outrem exposto à morte (LÉVINAS, 2011, p. 155).

Por outro lado, como o encontro com outrem não se esgota no amor da relação binária porque, afinal, advém no bojo da relação ética o advento do terceiro (LÉVINAS, 1997a, p. 247) que se apresenta como alteridade e infinito para a relação entre mim e Rosto, não há como não ter de se buscar uma "sabedoria do amor a serviço do amor" (LÉVINAS, 1997a, p. 144). Em outras palavras, a partir da entrada do terceiro na relação, a filosofia retoma seu estatuto ontológico que faz apelo à Razão (LÉVINAS, 1997a, p. 248), embora agora o pense a partir da "justiça para além da ética" como forma de expressão desse saber paradoxal coetâneo de uma metafísica pós-metafísica. Isso se deve ao fato de que, segundo Lévinas, se não houvesse ordem de Justiça, não haveria limite para minha responsabilidade. Por isso acrescenta certa medida da violência necessária a partir da Justiça. Embora não a descole da relação com o Rosto, pois é "de mim diante de outrem que se pode falar da legitimidade do Estado ou de sua não-legitimidade” (LÉVINAS, 1997a, p. 145-146). Daí a justificativa de um pensamento paradoxal que, se por um lado, opõe-se radicalmente à violência, por outro, admite certo grau de violência em nome da justiça. Eis que por isso a filosofia da alteridade seja identificada a uma Sabedoria da justiça a serviço da generosidade e do amor ético (LÉVINAS, 2011, p. 75).

Há, em certo momento, necessidade de pesagem, duma comparação, do pensamento, e a filosofia seria, nesse sentido, a aparição da sabedoria a partir do âmago desta caridade inicial: ela seria - e não brinco com as palavras - a sabedoria desta caridade, sabedoria do amor. (LÉVINAS, 1997a, p. 144).

Aliás, essa não coincide em nada com a pretensão heideggeriana de praticar uma repetição da filosofia ao modo de uma ontologia contra a violência da ôntica. Antes, as questões ontológicas e, portanto, da ordem do Logos, presentes na pós-metafísica, estão 
pautadas pela entrada do próximo do meu próximo, que rechaça, terminantemente, a indiferença do ser ao outro e ao terceiro, como próximo de meu próximo.

\begin{abstract}
A multiplicidade humana não permite ao Eu - digo não me permite - esquecer o terceiro que me arranca da proximidade do outro [...]. É hora da justiça. O amor do próximo e seu direito original de único e incomparável pelos quais tenho que responder vêm eles mesmos fazer apelo à Razão capaz de comparar os incomparáveis, a uma sabedoria do amor. Uma medida se sobrepõe à extravagante generosidade do para o outro, a seu infinito. Aqui o direito do único, o direito original do homem postula o julgamento e, consequentemente, a objetividade, a objetivação, a tematização, a síntese. Há necessidade de instituições que arbitrem e uma autoridade política que a sustente. A justiça exige e funda o Estado. (LÉVINAS, 1997a, p. 248).
\end{abstract}

Em última instância, a abordagem dessa temática de fundo em torno da reabilitação do paradoxo do outro em função do outro do outro na filosofia visa suscitar em nós o confronto com situações humanas hodiernas, nas quais a banalidade do mal as aflige de modo aviltante, bem como, nesse ínterim, seja possível tocar na hipérbole da bondade das relações humanas de modo a contradizer àquela, sobretudo se se pensa a condição humana a partir da filosofia que não se distancia da facticidade da vida (LÉVINAS, 1997b, p. 111), da existência vivida polarizada em torno do Rosto e do Terceiro, na ética e na justiça (LÉVINAS, 1997a, p. 247). Dela brota o paradoxo em função da contemporaneidade do excesso da bondade e da violência necessária da justiça. Em suma, isso significa ter de admitir que tanto a bondade como a violência não eximem sequer o pensamento, a linguagem que as pensa, porque essas não se descolam da existência vivida como linguagem do próprio corpo a corpo com o Rosto de outrem e com o terceiro da relação.

Ora, essa situação nos remonta a outra muito concreta do pensamento filosófico: se por um lado, trata-se de opor-se à violência por meio da justiça, isso significa que a bondade e o excesso de generosidade que se instauram no mundo por meio da ética, da relação com o outro, necessita por sua vez ser respaldada pela justiça (LÉVINAS, 1997a, p. 144). E o exercício concreto desta supõe ter de lidar com o paradoxo de ter de praticar certa ponderação, delimitação e medida da bondade por meio do confronto com a Lei e com o Direito (LÉVINAS, 1997a, p. 145). E isso significa ter de admitir que a lei, a medida, a comparação e o diálogo que interditam o excesso do amor devem formular limites para a bondade ou para o amor ético, a fim de que este não seja injusto, isto é, não esteja apenas no horizonte das intenções e, portanto, no mundo das abstrações.

Do mesmo modo, a justiça ou a justa medida que compara os diferentes e que os 
nivela segundo a lei a fim de pôr limite à bondade deve, por sua vez, ser continuamente inspirada pela desmedida (injusta) da ética a fim de que a justiça não se torne uma justiça injusta. Isso ocorre quando a justiça não leva em conta os diferentemente outros da relação. E essa breve descrição inserida aqui, da intriga que se estabelece entre amor e justiça, aponta para a condição paradoxal da existência e, portanto, da filosofia que não se pratica fora da existência, e que a remete ao seu caráter individual, público, cósmico, transcendente etc. atravessada pela ambiguidade, pela incerteza, pelo provisório no qual a violência e a bondade se mesclam, se alternam e se produzem sem purismos nem dicotomias. Isso, porém, não significa ceder lugar a uma espécie de domesticação do contentamento com aquilo que é dado a priori, como se se conformasse com o real tal como é, sem que se possa dele escapar. Daí que a filosofia, impossibilitada de se descolar da situação humana encarnada do contato com outrem, se vê interpelada a não filosofar sem levar em conta os intransponíveis paradoxos que a Metafísica tentou dissuadir-se sem sucesso em nome da certeza da Razão. Em contrapartida, a metafísica da alteridade se dá conta de que para aquém e além da Razão está o Rosto humano a interpelar por amor e justiça.

À guisa de conclusão pode-se dizer que no amor, na generosidade, na bondade ou na ética, dá-se uma "significação que a própria razão desconhece" porque sua lógica se expressa na justiça (LÉVINAS, 1987, p. 56). E esta, graças à inspiração da ética, se revela sempre mais racional do que a própria Razão. Pois, àquela a quem atribuímos a virtude de interromper a violência - para atingir a ordem da paz -, supõe a passividade ou a paciência. Nesse desinteressamento - quando responsabilidade pelo outro, ele é também responsabilidade pelo terceiro -, desenha-se a justiça que compara, reúne e pensa a sincronia do ser e da paz (LÉVINAS, 2011, p. 37).

\section{REFERÊNCIAS}

BENOIST, Jocelyn. Les limites de l'intentionalité. Recherches phénoménologiques et analytiques. Paris: Jvrin, 2005.

DERRIDA, Jacques. A voz e o fenômeno. Lisboa: Edições 70, 1996.

DERRIDA, Jacques. Violence et Métaphysique. Essai sur la pensée d'Emmanuel Levinas In: DERRIDA, Jacques. L'ecriture et la différence. Paris: Cerf, 1967, p. 117-228.

FERRARIS, Maurizio. La fenomenologia e il Messia. Aut aut, Milano, 1999, p. 167-182.

LEVINAS, Emmanuel. Entre nós. Ensaios sobre a alteridade. São Paulo: Vozes, 1997a. 
LEVINAS, Emmanuel. De Deus que vem à ideia. São Paulo: Vozes, 2002.

LEVINAS, Emmanuel. De outro modo que ser ou para lá da essência. Lisboa: Centro de Filosofia da Universidade de Lisboa, 2011.

LEVINAS, Emmanuel. Descobrindo a existência com Husserl e Heidegger. Lisboa: Piaget, 1997b.

LEVINAS, Emmanuel. Difficile liberté. Essais sur le judaisme. Paris: Albin Michel, 1976.

LEVINAS, Emmanuel. Hors Sujet. Paris: Fata Morgana, 1987.

LEVINAS, Emmanuel. Les imprévus de l’histoire. Paris: Fata Morgana, 1994.

LEVINAS, Emmanuel. Noms propres. Paris: Fata Morgana, 2014.

LEVINAS, Emmanuel. Totalidade e infinito. Lisboa. Edições 70, 1988.

MERLEAU-PONTY, Maurice. Fenomenologia da percepção. São Paulo: Martins Fontes Editora, 1994.

MERLEAU-PONTY, Maurice. Sinais. São Paulo: Editorial Minotauro, 1965.

NANCY, Jean-Luc. Um pensamento finito. Barcelona: Anthropos Editorial, 2002.

RICOEUR, Paul. Escritos e conferências 2. Hermenêutica. São Paulo: Loyola, 2011.

SLOTERDIJK, Peter. Regras para o parque humano. Uma resposta à carta de Heidegger sobre o humanismo. São Paulo: Estação Liberdade, 2000.

VIVEIROS DE CASTRO, Eduardo. Metafísicas canibais. Elementos para uma antropologia pós-estrutural. São Paulo: Cosac Naify, 2015. 